\title{
DETERMINANTESPSICOLINGÜÍSTICOSDACOMPREENSÃODELEITURAEMINGLÊS COMOLÍNGUAESTRANGEIRA
}

\author{
Javier Vivaldo-Lima \\ Miguel López-Olivas ${ }^{2}$ \\ Rosa Obdulia González-Robles ${ }^{3}$
}

\section{Resumo}

O objetivo deste estudo foi analisar a contribuição das variáveis lingüísticas e psicológicas da variância associada à compreensão de leitura em inglês (L2). A amostra esteve integrada por 280 estudantes universitarios, falantes nativos do espanhol. A dimensão lingüística da análise avaliou a influência das habilidades de processamento de texto do leitor em espanhol (L1), da sua competência lingüística em L2 e da sua habilidade para perceber transparência léxica entre as duas línguas, enquanto a dimensão psicológica analisou a influência do estilo cognoscitivo, do locus de controle e do controle de ação sobre a capacidade do leitor para construir significado a partir do texto. Administrou-se aos sujeitos uma bateria de sete instrumentos de avaliação. Uma série de análise de regressão múltipla indicou a existência dum modelo explicativo da leitura em L2 em duas etapas. Na primeira, as variáveis psicológicas explicaram $10.2 \%$ da variância associada ao processamento do texto em L1, variável que, na segunda etapa, explicou $35.8 \%$ da variância associada à compreensão de leitura em inglês, ajuntada à competência lingüística do leitor em L2 e à sua capacidade para perceber transparência léxica entre L1 e L2.

Palavras chave: Compreensão de leitura em inglês; Competência lingüística.

\section{Psycholinguistic Determinants of Reading Comprehension in English as a Foreign Language}

\begin{abstract}
The purpose of this study was to analyze the contribution of linguistic and psychological variables in the explanation of the variance associated with reading comprehension in English (L2). Two hundred and eighty Mexican university students participated in the study. The variables analyzed within the linguistic dimension were: reading strategies in Spanish, linguistic competence in English, and ability to perceive lexical transparency between L1 and L2. The psychological dimension evaluated the influence of the reader's cognitive style, locus of control, and action control orientation on reading comprehension in L2. Subjects were administered a battery of seven evaluation instruments. Multiple regression analyses suggested a two-stage explanatory model of reading in L2. Firstly, psychological variables accounted for $10.0 \%$ of the variance in reading comprehension in the first language. Secondly, reading comprehension in Spanish, linguistic competence in L2, and perception of lexical transparency, accounted for $35.5 \%$ of the variance in reading comprehension in English.
\end{abstract}

Key words: Reading comprehension, foreign language, psycholinguistic research.

\section{INTRODUCTION}

The ability to read proficiently in at least one foreign language has become a major requirement of the curricula of institutions of higher education throughout the world. This increasing demand for proficiency in specific skills in foreign languages (reading being the most outstanding) has led to the development of courses for specific objectives, designed to meet concrete academic priorities.

Given the current need to improve the reading skills of our university students, it is considered of utmost importance to achieve a deep comprehension of the mechanisms, processes, and variables that promote the acquisition of relevant discourse processing skills in a second or a foreign language, with particular emphasis on reading. Such understanding would address a major research priority (Pugh \& Ulijn, 1984) and promote the development of research-grounded instructional approaches in the field.

Fearch and Kasper (1986) have stressed the need to extrapolate the research done in the field of reading in a

\footnotetext{
${ }^{1}$ Universidad Autónoma Metropolitana, Unidad Iztapalapa - Área de Investigación en Lenguas y Culturas Extranjeras

${ }^{2}$ Universidad Nacional Autónoma de México - Facultad de Psicología.

${ }^{3}$ Universidad Autónoma Metropolitana - Unidad Iztapalapa - Departamento de Matemáticas.
} 
first language (L1) to the study of reading processes in foreign languages (L2) with specific reference to the development of reading comprehension models, the formulation of research hypothesis, and the selection of relevant instructional methodologies. They contend that although the reader's linguistic competence in L2 may play an important role in the construction of meaning from text in a foreign language, it is not necessarily the main determinant, considering the facilitation effect associated with the reader's knowledge of the linguistic system of the L1 and its strategic application.

The problem

A constant found among students registered in reading comprehension courses in English at the Universidad Autónoma Metroplitana in Mexico is their wide variation in reading achievement, variation that can not be uniquely associated with deficits in linguistic competence in L2. That is, although most of our students enter with a limited linguistic competence in English, some of them eventually develop powerful reading comprehension strategies, and achieve an efficient comprehension of textual information in L2, thus overcoming their original linguistic limitations. However, cases of students with rigid and inefficient text processing strategies are invariably detected, most of them showing a lack of ability to integrate to their reading repertoires strategies which demand a flexible and interactive processing of information.

Hence, and although the utmost importance of linguistic determinants for $\mathrm{L} 2$ reading comprehension is acknowledged, this study is based on the assumption that the construction of meaning from text in a foreign language may also be determined by psychological factors associated with the reader's perceptual, cognitive and volitional orientation. In such regard, the main purpose of this study is to validate a multivariate model of reading comprehension in L2 integrated by two main explanatory dimensions of analysis: the linguistic and the psychological.

\section{Conceptualization of the reading process}

The theoretical approach to reading comprehension that underlies this research is based on the Strategic Model of Discourse Processing developed by Van Dijk and Kintsch (1983). Discourse processing is conceptualized as a strategic and interactive process in which the reader constructs a mental representation of discourse in memory using both external information (the text) and internal information (cognitive presuppositions). Discourse is analyzed from the word as the basic unit at the lower level to whole themes as units at the higher level, with a continuous interaction among different text processing levels. In their words: "The model moves from the comprehension of words to the comprehension of clauses in which words have different functions, and from there to complex sentences, sentence sequences and whole textual structures, with a continuous feedback existing among less and more complex units ... instead of operating with a conventional structural processing model we operate with a strategic model"(p. 10).

\section{The model}

The model evaluated in this study (figure 1) is based on the tenet that the variability observed in academic reading comprehension in English in Mexican university students can be accounted for by the interaction of two linguistic and psychological variables. The first dimension of the model (linguistic) is threefold and analyses the impact of (1) the reader's strategies in his/her first language (Spanish), (2) his/her level of linguistic competence in the foreign language (English), and (3) his/her ability to perceive lexical transparency between both languages (cognate perception). On the other hand, the psychological dimension, which is also threefold, evaluates the influence of the reader's cognitive style, locus of control and action control orientation on her/his construction of meaning from text.
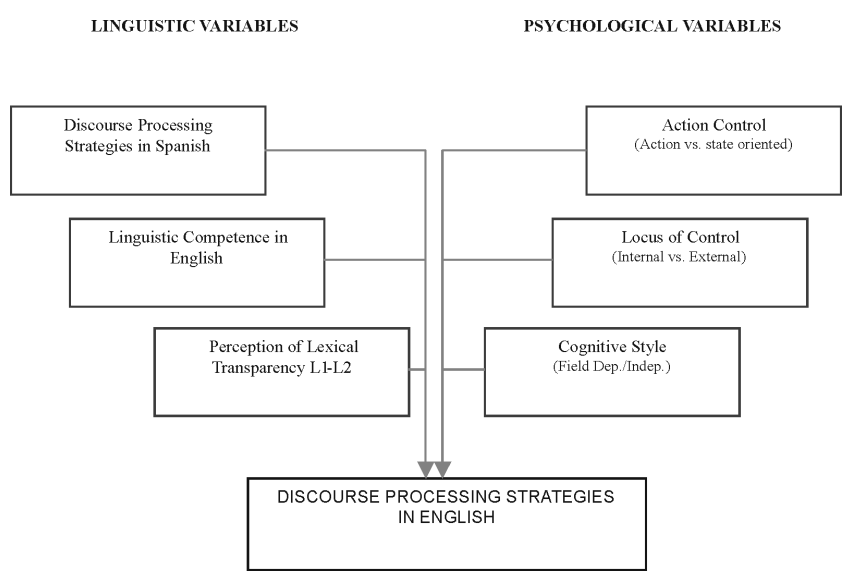

Figure 1: A multivariate model of linguistic and psychological determinants of reading. Original proposal.

Following, a summarized revision of the variables incorporated in the proposed model is presented in order to provide a theoretical and research background to the reader. 
Reading comprehension in Spanish. The first variable proposed in the explanation of the reading performance of university students in English is their ability to strategically process textual information in their first language. Its integration into the model was based on theoretical considerations about the preeminent role of the first language in the acquisition of a foreign language. In such regard, Beaugrande (1984) underscored the decisive influence of the learner's knowledge of L1 in learning a foreign language, and proposed that the mother tongue plays the role of a metamodel of language (of a set of expectancies regarding the way in which any particular language is organized), which according to him, would eventually adjust to accommodate the divergence among the L1 and the L2.

Linguistic Competence in English. The importance of linguistic competence in L2 for reading comprehension has been vastly acknowledged, although perhaps underestimated in current L2 teaching methodologies. Specifically, Beck and Carpenter (1986) propose the existence of a "threshold level" of linguistic competence for reading, which may fluctuate according to specific task demands but, below which, a reader cannot construct meaning from text. Williams and Moran (1989), on the other hand, make reference to a "linguistic ceiling" for reading which, if extremely low, "would limit the ability of the reader to interact with the text" (p. 221).

Perception of Lexical Transparency between L1 and L2. According to a conceptualization of reading as a strategic process, it was considered that the ability to perceive and exploit cognate relationships between L1 and L2 would become a most powerful strategy in reading, helping the reader to overcome limitations in his/her lexical repertoire. Such contention has also been endorsed by Beaugrande (1984) in the following terms: "If we presuppose the existence of a general memory store for both languages (the native and the foreign), all tactics that lead from elements in the mother tongue to their equivalents in the foreign language help to enhance both the efficiency and the search in memory improving familiarity ... the similarity supports learning enabling the transference of elements, assumptions, and processes already familiar" (p.10).

Cognitive Style. Cognitive style is defined as the typical way to solve problems, think and perceive of a given subject. Research literature in the field makes reference to several categorizations of the construct including field dependence-independence, conceptual tempo, and attentional style, among others. This study centers in the analysis of the first of these categories given its relevance to the study of reading as a complex problem-solving skill as well as the vast amount of experimental research relating cognitive style and reading comprehension. According to Witkin (in Pitts \& Thompson, 1984), the field independent (FI) person has a greater ability to discover outstanding features in a complex field as well as to react to ambiguous stimuli in an analytical way, while the field dependent (FD) person visualizes patterns more globally. Field independence has also been associated with a greater articulation and competence in cognitive analysis and restructuring, while field dependence has been related to a more global approach and to a greater interpersonal competence. Research on the relationship between reading comprehension and cognitive style has shown that FI readers are more capable of making inferences than their dependent counterparts when confronted with tasks that demand an inferential interpretation from prose; that FD subjects tend to constrain their reasoning to real events, whereas FI individuals consider multiple alternatives (Linn, 1978); and that FD readers strongly rely on information in the text, not exploiting their previous knowledge as efficiently as FI independent subjects (Spiro \& Tirre, 1980).

Locus of Control. Locus of control is defined as a set of generalized expectancies that reflect consistent individual differences among subjects regarding the extent to which they perceive a contingency between their behavior and subsequent events. According to Strickland (1989), subjects with an internal locus of control perceive a contingency between their own behavior and subsequent events, whereas individuals with an external orientation have more probability of perceiving those events as resulting from fate, chance or circumstances beyond their personal control. Research literature in the field includes studies analyzing the relationship between locus of control and intentional and incidental memorization (Beaule \& Mckelvie, 1986), and locus of control and academic achievement (Mwamwenda \& Mwamwenda, 1986). Findley and Cooper (1988) report a literature review of 98 research studies analyzing the relationship between locus of control and academic achievement. According with their results, internal control beliefs showed to be consistently and significantly correlated with higher academic achievement. 
Action Control. The construct of action control, advanced by Kuhl (1987), refers to a meta-cognitive process that mediates the execution of an action related to an intention of an individual. The process organizes and controls cognitive operations, such as selective attention and the amount and quality of information processed in a way that maximizes the congruence between intention and performance. The extent of action control evoked in a particular situation varies along the two ends of a continuum between action and state orientation. State-oriented cognitions do not evoke any tendency to action but can actively inhibit the expression of action tendencies as a result of a partial incompatibility between action and state orientation. That is, according to Kuhl (1987), in a complex problem-solving situation, as the amount of state-oriented cognitions increases, the likelihood that the individual performs an expected action tends to decrease. It is assumed that an action that demands complex preparatory planning cannot be carried out when the organism is state-oriented since part of the attentional capacity required is employed in state-oriented processes. Research studies focused on the analysis of the relationship between action control and reading comprehension are not reported in the literature. Nevertheless, based on a conceptualization of the reading process in L2 as a complex problemsolving endeavor, and on the results of preliminary exploratory studies conducted with Mexican university students, it was considered that the reader's action control orientation may also contribute to explain the variability in $\mathrm{L} 2$.

\section{Research hypothesis}

As can be concluded from the previous revision of literature, the individual influence on reading comprehension of the linguistic and psychological variables incorporated into the model has been documented on the research literature. However, no previous attempts to integrate the two dimensions into a single, comprehensive model of reading have been reported. Therefore, the purpose of this study was to examine the explanatory power of a multivariate model of reading centered around two dimensions of analysis: the linguistic and the psychological. The model was translated into the following research hypothesis

Reading comprehension in English in Mexican university students, native speakers of Spanish, is a function of their level of reading comprehension in
Spanish (reading strategies in L1); of their level of linguistic competence in the foreign language; of their ability to perceive lexical transparency between both the first and the foreign language; of their cognitive style (field dependence vs. field independence); of their locus of control (internal vs. external); and of the type of action control orientation.

\section{METHOD}

Participants. Two hundred and eighty voluntary undergraduate college students from two Mexican public universities participated in the study, 118 males and 162 females. As to the institution of reference, 105 were from the Universidad Nacional Autónoma de México (UNAM) and 175 from the Universidad Autónoma Metropolitana (UAM).

Instruments. The evaluation of the sample was based on the administration of a battery of tests integrated by the following instruments: (1) Test of Discourse Processing in English as a Foreign Language (Vivaldo, 1994); (2) Test of Discourse Processing in Spanish as a First Language (Vivaldo, 1994); (3) Nelson English Language Test-Level 150 (Fowler \& Coe, 1976); (4) Test of Perception of Lexical Transparency between English and Spanish (Vivaldo, 1992); (5) The Embedded Figures Test (Witkin, Oltman, Raskin \& Karp, 1971); (6) Internality-Externality Scale (Romero-García \& Pérez, 1983); and (7) Action Control Scale (Kuhl, 1990). Following a brief description of each instrument is presented.

Tests of Discourse Processing Strategies in English and Spanish. Two equivalent tests for the evaluation of reading comprehension in English and Spanish were developed specifically for the study. The theoretical and methodological approach to the evaluation of reading comprehension was based on an extrapolation of the strategic model of discourse processing developed by Van Dijk and Kintsch (1983). The evaluation involved the analysis of the reader's performance at the following major levels of discourse processing: schematic, macro propositional, local coherence and propositional.

Given that a major methodological challenge of the study was to assure the equivalence between the evaluation of reading strategies in English and in Spanish, a major consideration in the design of these instruments 
was to control for textual variables (text length, lexical density, conceptual density, structure, typographical clues).

Multiple-choice items evaluating the reader's performance on each of the four main levels of strategic discourse processing proposed by Van Dijk and Kintsch (1983) were developed for each text. Items were presented in Spanish in both tests in order to avoid additional task demands associated to the understanding of the evaluation items in the foreign language. Final versions of the tests were revised and piloted using teachers of English as judges. The final version for each instruments contained 45 items classified as follows:

Sections 1 and 2. Macropropositional Level (Items 1-17) Included 10 multiple choice and 7 true-false items evaluating the ability of the reader to discriminate and integrate the main macro ideas in the text both at a global and at a local level.

Section 3. Local Coherence Level (Items 18-25). Included 8 multiple-choice items centered on the evaluation of contextual referents within the text, as well as on the ability of the reader to follow the argumentative network in the text.

Section 4. Propositional Level (Items 26-40). This section was based on a "cloze" format and focused on the evaluation of the reader's ability to integrate syntactic, morphological, discursive, lexical and grammatical information at a propositional level.

Test of Perception of Lexical Transparency between $L 1$ and L2. The test measured the ability of the reader to perceive cognates (words sharing both similar form and meaning in two languages) within an academic text. The test was based on a short expository text about chemistry ("The Nobel Prizes"), published in Scientific American. The text was initially piloted with a group of experts who were asked to underline all English-Spanish cognates included in it, with exact registration made of their response times. From the previous procedure 134 words were categorized as cognates (those words selected as such by all the experts). On the other hand, and according to the mean response time between experts, a response time of 5 min. was established for the administration of the test (the idea being to obtain an indicator of the reader's first impression during a first read of the article and not of a word-by word analytical process not natural during normal reading). The grading for the test ranges between 0 (minimum possible value) and 134 (maximum possible value).
Action Control Scale. The Action Control Scale (Kuhl, 1991) is a 36-item instrument divided into three subscales (action control during performance, failure and decision taking). Each subscale is integrated by 12 items describing particular problem situations. For each situation the subject is given an alternative between two possible response alternatives, either A or B (one oriented towards action and the other towards an emotional state). The grading of the subjects' responses for each subscale is based o the count of the total of action-oriented responses (between 0 and 12). In order to provide for effects associated with item presentation, items are distributed at random as well as options A and B. In the case of this study, only the subject's scores for the AOF scale were taken into consideration.

Levenson Internality-Externality Scale. (RomeroGarcía \& Pérez, 1985). This instrument is centered on the analysis of the subjects' locus of control within an internal-external dimension. It includes 24 Likert-type items ranging between 0 (totally disagree) and 6 (totally agree). The total internality score for the subject (IT) is obtained adding separately the scores for each one of the three subscales of the instrument.

Procedure. Administration of instruments was carried out on a group basis and involved three twohour sessions per group. A total of 27 group sessions were held (9 groups analyzed). The administration of reading comprehension tests was carried out on the basis of a counterbalance procedure regarding the following criteria: (1) order of language evaluation (L1 or L2); and (2) version of exam administered (Text A or Text B in each language). Statistical analyses included a series of descriptive, correlational, and multiple regression analyses, an were conducted using the Statistical Package for Social Sciences (SPSS).

\section{RESULTS}

The final sample for the study included 280 undergraduate college students, 118 males (42.1\%) and 162 females $(57.9 \%)$. The mean age for the sample 23.06 years. 105 of the participants were from the UNAM whereas 175 of them were students at UAM. As to their field of studies, 208 (74.3\%) were from the Division of Social Sciences and Humanities; 38 (13.6\%) from the Division of Basic Sciences and Engineering; and 34 (12.0\% from the Division of Biological and Health Sciences. 
The descriptive analysis of the main variables under study yielded the following results: (1) Reading comprehension in English: mean score of 19.32, equivalent to 52/100, with an standard deviation of 4.99; (2) Reading comprehension in Spanish: mean score of 25.62 (equivalent to 69/100) with a standard deviation of 4.75; (3) Linguistic competence in English: mean score of 15.85 (equivalent to 31/100) with a standard deviation of 5.87; (4) Perception of lexical transparency between English and Spanish: mean score of 93.8 (equivalent to $69 \%$ of correctly identified cognates within the corresponding test) with a standard deviation of 19.46; (5) Cognitive style: mean score of 9.55 (slightly above de median of possible scores for such test) with a standard deviation of 4.72; (6) Locus of control: mean score of 20.24 (slightly above the median of possible scores for the corresponding test 20) with a standard deviation of 6.84 , (7) Action Orientation (AOF subscale): mean score of 6.57 (slightly above the median of possible scores for the corresponding subscale of Kuhl's scale $=6.0$ ) with a standard deviation of 6.57 .

Multiple regression analysis. The regression model originally proposed to explain the variability of reading comprehension in English (RCE) -Model 1estimated from the scores of the 280 subjects included in the sample under study, yielded the following results (Table 1): An F=25.46627 for the associated analysis of variance, indicating a significant regression of model 1 ( $p<0.01$ ), a multiple correlation coefficient of 0.59904 (Multiple R), and a determination coefficient of 0.35885 (R. Square), indicating that the independent variables explained $35.88 \%$ of the variability in discourse processing in English under Model 1.

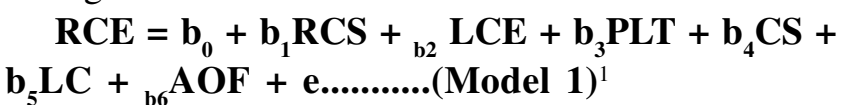

Table 1: Multiple regression analysis. Model 1.

\begin{tabular}{|c|c|c|c|c|c|}
\hline Equat on Number 1 & \multicolumn{5}{|c|}{ Dependent Variable: Text processing strategies in English } \\
\hline $\begin{array}{c}\text { Model } \\
1\end{array}$ & $\begin{array}{c}\mathbf{R} \\
.59904 \\
\end{array}$ & \multirow{2}{*}{$\begin{array}{c}\text { R Square } \\
.35885 \\
\text { df }\end{array}$} & \multirow{2}{*}{$\begin{array}{c}\text { Adjusted } \\
\text { R Square } \\
.34476 \\
\text { Mean } \\
\text { Square } \\
415.75357\end{array}$} & \multicolumn{2}{|c|}{$\begin{array}{c}\text { Std. error of the } \\
\text { estimate } \\
4.04050\end{array}$} \\
\hline \multirow[t]{3}{*}{$\begin{array}{c}\text { Model } \\
1\end{array}$} & $\begin{array}{c}\text { Sum of } \\
\text { Squares } \\
2494.52140\end{array}$ & & & $\begin{array}{c}\mathbf{F} \\
25.4662\end{array}$ & $\begin{array}{l}\text { Sig. } \\
.0000\end{array}$ \\
\hline & 4456.90360 & 273 & 16.32565 & 7 & \\
\hline & \multicolumn{2}{|c|}{$\begin{array}{l}\text { Unstandardized } \\
\text { Coefficients }\end{array}$} & $\begin{array}{c}\text { Standardized } \\
\text { Coefficients } \\
\text { Beta }\end{array}$ & $\mathbf{T}$ & Sig. \\
\hline \multicolumn{6}{|l|}{ Variable } \\
\hline Act on contro & $\begin{array}{l}1.970965 \mathrm{E}- \\
04\end{array}$ & .08834 & $1.1338 \mathrm{E}-04$ & .002 & .9982 \\
\hline $\begin{array}{l}\text { Perception of lexica } \\
\text { transparency }\end{array}$ & .02359 & .01288 & .09199 & 1.832 & .0500 \\
\hline $\begin{array}{r}\text { Linguistic competence in } \\
\text { English }\end{array}$ & .27532 & .04393 & .32762 & 6.268 & .0000 \\
\hline Cognitive style & .05454 & .05334 & .05158 & 1.022 & .3075 \\
\hline \multirow{2}{*}{$\begin{array}{r}\text { Locus of contro } \\
\text { Discourse processing in } \\
\text { Spanish }\end{array}$} & -.02047 & .03779 & -.02804 & -.542 & .5886 \\
\hline & .38578 & .05703 & .36709 & 6.764 & .0000 \\
\hline (Constant) & 2.76826 & 1.76047 & & 1.572 & .1170 \\
\hline
\end{tabular}


However, under Model 1 only three variables showed to be significant, namely, reading comprehension in Spanish, linguistic competence in English and perception of lexical transparency between L1 and L2 ( $p<0.0000$; 0.0000 ; and 0.05 , respectively). Therefore, alternative models were examined, withdrawing each of the nonsignificant variables. Models with 5, 4 and 3 independent variables were tested. The model with three independent variables (RCS, LCE, and PLT) was the only one in which all explanatory variables were significant (Table 2 - "Sig T column").

$\mathrm{RCE}=\mathrm{b}_{0}+\mathrm{b}_{1} \mathrm{RCS}+{ }_{\mathrm{b} 2} \mathrm{LCE}+\mathrm{b}_{3} \mathrm{PLT}+$ e..............................(Model 2) hypothesized that they could have not a direct but an indirect influence on he discourse processing skills in English. That is, it could be the case that the psychological variables did not explain RCE in the presence of RCS, LCI and PLT due to the fact that they could be involved in the explanation of the variability of any of those variables. Hence, and as a first step in such direction, it was decided to analyze the influence of the reader's cognitive style, locus of control and action control on his/her text processing skills in Spanish, based on the following considerations: (1) The knowledge of the first language is considered to be play the role of a metamodel in the acquisition of a foreign language

Table 2: Multiple regression analysis. Model 2.

\begin{tabular}{|c|c|c|c|c|c|}
\hline \multirow{2}{*}{$\begin{array}{c}\text { Equation Number } 2 \\
\text { Model } \\
2\end{array}$} & \multirow{2}{*}{$\begin{array}{c}\text { dent Variable } \\
\mathbf{R} \\
.59652 \\
\end{array}$} & \multirow{2}{*}{$\begin{array}{c}\text { Cext process } \\
\text { R Square } \\
.35584 \\
\end{array}$} & \multirow{3}{*}{$\begin{array}{c}\text { ng strategies in } \\
\text { Adjusted } \\
\text { R Square } \\
.34884 \\
\text { Mean } \\
\text { Square }\end{array}$} & \multirow{2}{*}{\multicolumn{2}{|c|}{$\begin{array}{l}\text { English } \\
\text { Std. error of the } \\
\text { estimate } \\
4.02720\end{array}$}} \\
\hline & & & & & \\
\hline $\begin{array}{l}\text { Regression } \\
\text { Residual }\end{array}$ & $\begin{array}{c}\text { Sum of } \\
\text { Squares } \\
2473.50168 \\
4477.82332 \\
\end{array}$ & $\begin{array}{c}3 \\
276\end{array}$ & & $\begin{array}{c}F \\
50.821 \\
87\end{array}$ & $\begin{array}{l}\text { Sig. } \\
.0000\end{array}$ \\
\hline & \multicolumn{2}{|c|}{$\begin{array}{l}\text { Unstandardized } \\
\text { Coefficients }\end{array}$} & $\begin{array}{l}\text { Standardized } \\
\text { Coefficients }\end{array}$ & & \\
\hline $\begin{array}{r}\text { Variable } \\
\text { Perception of lexical } \\
\text { transparency }\end{array}$ & $\begin{array}{c}\mathbf{B} \\
.02530\end{array}$ & $\begin{array}{l}\text { Std. Error } \\
.01275\end{array}$ & $\begin{array}{l}\text { Beta } \\
.09864\end{array}$ & $\begin{array}{c}\mathbf{T} \\
1.985\end{array}$ & $\begin{array}{l}\text { Sig. } \\
.0482\end{array}$ \\
\hline $\begin{array}{r}\text { Linguistic competence in } \\
\text { English }\end{array}$ & .27944 & .04341 & .32846 & 6.437 & .0000 \\
\hline $\begin{array}{r}\text { Text processing in Spanish } \\
\text { (Constant) }\end{array}$ & $\begin{array}{l}.38847 \\
2.58290\end{array}$ & $\begin{array}{c}.05449 \\
1.60512\end{array}$ & .36965 & $\begin{array}{l}7.130 \\
1.609\end{array}$ & $\begin{array}{l}.0000 \\
.1087\end{array}$ \\
\hline
\end{tabular}

The regression analysis for Model 2 (Table 2) yielded a multiple correlation coefficient of 0.59652 , a determination coefficient of 0.35584 (that is, RCS, LCE, and PLT explained $35.584 \%$ of RCE's variability under model 2, roughly equivalent to the percentage obtained under model 1), and an F value of 50.82 indicating the existence of a significant regression for model $2(\mathrm{p}<.01)$. Column " $\mathrm{B}$ " in Table 2 presents the estimators for the $\mathrm{b}_{0} \mathrm{~b}_{1, \mathrm{~b} 2}$ and $\mathrm{b}_{3}$ parameters, from which the following fit model was derived (Prediction Model):

$\mathrm{RCE}=\mathbf{2 . 5 8 2 9}+.38847 \mathrm{RCS}+.27944 \mathrm{LCI}+$ .0253 PLT..............Prediction Model

Nevertheless, and given the fact that the exclusion of the psychological variables from the original model contradicted to a certain extent research findings in the field suggesting their theoretical relevance, it was
(Beaugrande, 1984); (2) The analysis of correlations among variables showed that the correlations between text processing skills in Spanish and the psychological variables (Table 3) was stronger than that between the latter variables and linguistic competence in English or perception of lexical transparency between L1 and L2.

Hence, it was hypothesized that the psychological set of variables could exert a preliminary influence on reading comprehension in the first language which, in turn, could become a major determinant of reading comprehension in the foreign language. Accordingly, the following model was tested:

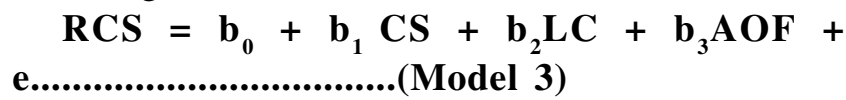

The results in Table 4 show a significant regression for Model $3(\mathrm{~F}=10.29472, \mathrm{p}<0.0001)$ with all three 
Javier Vivaldo-Lima M.A., Miguel López-Olivas PhD. e Rosa Obdulia González-Robles M.Sc.

Table 3: Analysis of correlations among variables.

\begin{tabular}{|c|c|c|c|c|c|c|c|}
\hline & RCE & RCS & LCE & PLT & CS & LC & AOF \\
\hline RCE & 1.0000 & $.4949^{\star *}$ & $.4583^{\star \star}$ & $2266^{\star *}$ & $.1979^{\star \star}$ & .0787 & -.0116 \\
\hline RCS & $.4949^{\star \star}$ & 1.0000 & $.3144^{\star \star}$ & & $.2226^{\star \star}$ & $.2109^{\star \star}$ & -.0682 \\
\hline LCE & $.4583^{\star \star}$ & $.3144^{\star \star}$ & 1.0000 & .1384 & $.1635^{*}$ & .0672 & .0646 \\
\hline PLT & $.2266^{\star *}$ & $.2232^{* *}$ & .1384 & 1.0000 & $.1621^{*}$ & .0169 & -.0249 \\
\hline cs & $.1979^{\star \star}$ & $.2226^{\star \star}$ & $.1635^{\star}$ & $.1621^{\star}$ & 1.0000 & .1168 & .0371 \\
\hline LC & .0787 & $.2109^{\star *}$ & .0672 & .0169 & .1168 & 1.0000 & $.2569^{\star *}$ \\
\hline AOF & -.0116 & -.0682 & .0646 & -.0249 & .0371 & $.2569^{\star *}$ & 1.0000 \\
\hline
\end{tabular}

independent variables (cognitive style, locus of control and action control) significant ( $\mathrm{p}<0.0256 ; \mathrm{p}<0.0005$ and $\mathrm{p}<0.0002$, respectively).

Furthermore, the three psychological variables explained $10.1 \%$ of the variability of reading comprehension in Spanish as indicated by the associated determination coefficient (R Square), with a multiple correlation coefficient of .31723 (Multiple R). The estimators for the model's coefficients generated the following prediction model:

$\mathrm{RCS}=22.0089+.20289 \mathrm{EC}+.15381 \mathrm{LC}-$ .21925 AOF.

Table 4: Multiple regression analysis - Model 3.

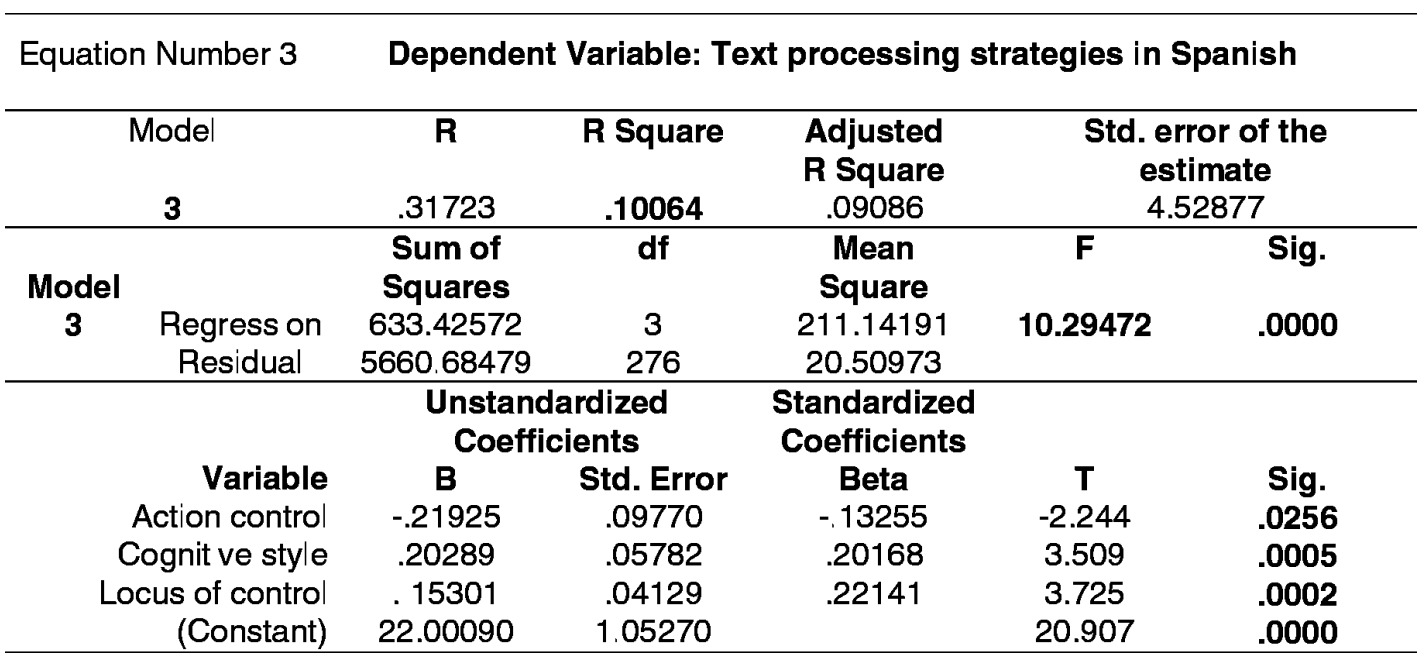

Notice that the weights for cognitive style (CS) and locus of control (LC) were positive as well as the correlation coefficients between reading comprehension in Spanish (RCS) and both, cognitive style and locus of control (Table 5). Hence, it is suggested that these two psychological variables are directly proportional to reading comprehension in Spanish. On the other hand, both the coefficient of action control in the predictive model as well as its correlation with reading comprehension in Spanish were negative, indicating that such variable is inversely proportional to RCS.

In short, in can be concluded that the last three variables in Model 1 (cognitive style, locus of control and action control) are not significant because what we 
actually have is a rather indirect effect of those variables a two-phase model which is explained as follows:

\section{PHASE 1}

Reading comprehension in Spanish is a function of the reader's cognitive style, locus of control, and action control orientation. Model 3

\section{PHASE 2}

Reading comprehension in English is a function of the reader's level of reader comprehension in Spanish, linguistic competence in English, and ability to perceive lexical transparency between L1 and L2. Model 2

\section{Discussionand Conclusions}

The main research hypothesis of this study was that that the variation in reading comprehension in English in Mexican university students was a function of the interaction of both linguistic variables (text processing strategies in L1, linguistic competence in L2 and perception of lexical transparency between L1 and L2) and psychological variables (cognitive style, locus of control and action control). However, and even though the influence of the aforementioned variables was partially validated from the series of regression analyses performed, it became evident that the explanation of the variability in reading comprehension in L2 was not straightforward (i.e., one that could be accounted for on the basis of the direct contribution of the complete set of originally proposed variables). Rather, such variability was partially explained on the basis of a two-stage process in which the influence of the three linguistic variables integrated into the model showed to be direct, whereas the influence of the three psychological variables was indirect (Figure 2).

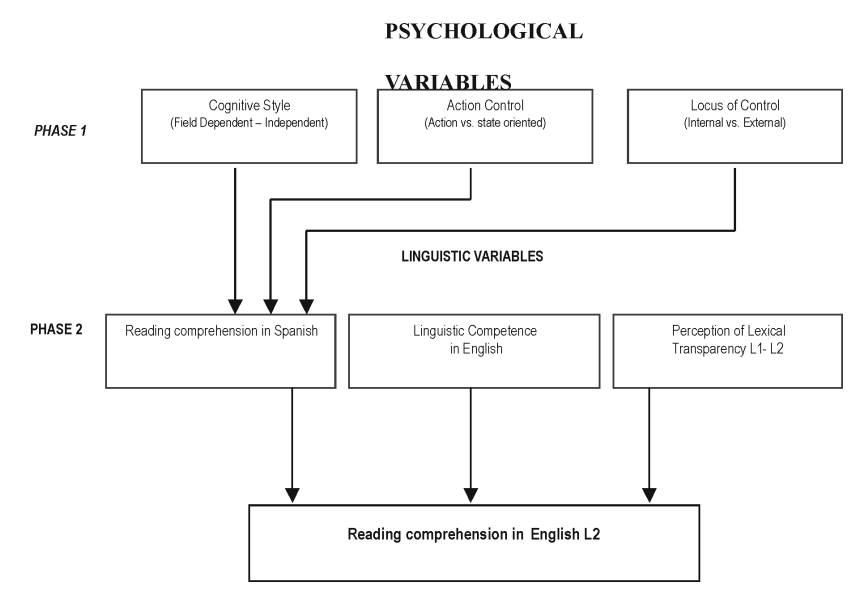

Figure 2: A preliminary explanatory model of text processing variability in English (L2).
Specifically, and as originally hypothesized, the readers' ability to process academic written discourse in English has shown to be a function of three major predictor variables, namely, reading comprehension in Spanish, linguistic competence in the foreign language, and ability to perceive lexical transparency between the two languages. In such regard, a model has been validated that accounts for an initial $35 \%$ of the variance of reading comprehension in English taking as predictor variables the three linguistic variables incorporated into the original model. On the other hand, and even though the set of psychological variables did not show a direct, significant contribution in the explanation of reading comprehension in English, an alternative multiple regression analysis, which considered the readers' text processing strategies in L1 as the dependent variable, revealed that the reader's cognitive style, locus of control and action control orientation have a slight, though significant contribution, in the explanation of the variability of text processing strategies in L1. Hence, given the fact that reading comprehension in Spanish constitute in our model the most important predictor of the variability associated with discourse processing in English, and that the former is in itself partially explained by the complete set of psychological variables, a two-stage explanatory model of reading in LLL2 is suggested from this study based on the following considerations.

First, it has been found that the ability of the reader to process written academic discourse in $\mathrm{L} 1$ is the most powerful predictor of his/her reading comprehension in the foreign language, maybe in the form of the metamodel of language proposed by Beaugrande (1984) paving the way for the extrapolation of reading strategies from L1 to L2. Second, text processing skills in English have also been explained by the reader's level of linguistic competence in the foreign language, competence that would represent the linguistic knowledge base of the reader and that would play a major role in the successful construction of meaning from text. Third, the ability to perceive and exploit lexical transparency between L1 and L2 has also been found to constitute a determinant of text processing ability in the foreign language.

Furthermore, it has been found that cognitive style, locus of control, and action control orientation function as indirect psychological mediators of reading comprehension in English, exerting an indirect impact on such variable via their influence on the reader's discourse processing 
ability in the first language, the first major predictor of L2 reading in our study. In such regard, it may be the case that the influence of psychological variables can be more strongly differentiated in the explanation of reading comprehension in $\mathrm{L} 1$ due to the fact that the reader would have already developed and internalized a sound spectrum of lexical, semantic, syntactic and grammatical decoding skills, thus making it more feasible to discriminate the differential impact of psychological variables, in themselves more distal to the central process under study. On the other hand, the impact of linguistic variables in the explanation of text processing variability in L2 would be expected to be more preeminent, since the readers' lexical, syntactic and grammatical repertories would tend to be more limited as a result of the limited level of linguistic competence in the foreign language. Hence, upon constructing meaning from text the specialized processes

\section{REFERENCES}

Afferbach, P. P. (1990). The influence of prior knowledge on expert readers' main idea construction strategies. Reading Research Quarterly, 25 (1), 31-41.

$\mathrm{Au}, \mathrm{K} . \mathrm{H}$. (1998). Social constructivism and the school literacy learning of students of diverse backgrounds. Journal of Literacy Research, 30 (2), 297-319.

Baddeley, A., Logie, R., Nimmo-Smith, I., \& Brereton, N. (1985). Components of fluent reading. Journal of Memory and Language, 24, 119-131.

Beaugrande, R. (1984) Reading skills for foreign languages: A processing approach. In A. K. Pugh \& J. M. Ulijn, J. M. (1984). Reading for professional purposes: Studies and practices in native and foreign languages. Heinemann: London.

Beaule, B., \& Mckelvie, S.J. (1986). Effects of locus of control and relevance on intentional and incidental memory for passages. Perceptual and Motor Skills, 63, 855-862.

Beck, I. L., \& Carpenter, P. E. (1986). Cognitive approaches to understanding reading. American Psychologist ${ }_{2}$ (October), 1098-1105.

Fearch, C., \& Kasper, G (1986). The role of comprehension in second language learning. Applied Linguistics, 7 (3), 257274.

Findley, M. J., \& Cooper, H.M. (1983). Locus of control and academic achievement: A literature review. Journal of Personality and Social Psychology, 44 (2), 419-427.

Fowler, W. S., \& Coe, N. (1976). Nelson English Language Tests. Hong Kong: Thomas Nelson \& Sons. associated with the linguistic dimension of analysis would constitute the strongest determinants in the construction of meaning from text.

To conclude, the model validated from this study provides a preliminary, non-exhaustive explanation of an otherwise extremely complex phenomenon: the development of academic written discourse processing skills in a foreign language. In such regard, further research is needed in order to broaden our explanatory framework, integrating the analysis of the contribution of additional predictive variables not considered in this investigation which may include vocabulary knowledge in L2 (Nation, 1983), lexical access (Baddeley, Loggie, NimmoSmith \& Brereton, 1985), previous knowledge (Afferbach, 1990); and socially-related factors (Parry, 1993; Street, 1993; Au, 1998)

Kuhl, J. (1987). Feeling vs. being helpless: Metacognitive mediation of failure-induced performance deficits. In F. E. Weinhart \& R. H. Klowe (Eds.). Metacognition, motivation and understanding. New Jersey: Lawrence Erlbaum Associates, Publishers.

Kuhl, J. (1991). Action versus state orientation. Psychometric properties of the Action Control Scale (ACS 90). In J. Kuhl \& J. Beckmann. (Eds.) Volition and Personality: Action versus State Orientation (pp.). Toronto: Göttingen Hogrefe.

Linn, M. C. (1978). Influence of cognitive style and training on tasks requiring the separation of variables schema. Child Development, 49, 874-877.

Nation, P. (1983). Testing and teaching Vocabulary. Guidelines, $5(1), 12-25$.

Mwamwenda, T. S., \& Mwamwenda, B. B. (1986). Transkenian students' Locus of Control and academic achievement. Psychological Reports, 59, 511-516.

Parry, K. (1993). The social construction of reading strategies: New directions for research. Journal of Research in Reading. 16 (2), 148-158.

Pitts, M. M., \& Thompson, B. (1984). Cognitive styles as mediating variables in inferential comprehension. Reading Research Quarterly, 19 (4), 426-435.

Pugh, A. K., \& Ulijn, J. M. (1984). Reading for Professional Purposes: Studies and Practices in Native and Foreign Languages. London: Heinemann.

Romero-García, O., \& Pérez de Maldonado, I. (1985). Escala Levenson de locus de control: Análisis factorial en Venezuela. Publicación 51. Mérida, Venezuela: Universidad de los Andes. 
Spiro, R. J., \& Tirre, W.C. (1980). Individual differences in schema utilization during discourse processing. Journal of Educational Psychology, 72, 204-208.

Street, B. V. (1993). The new literacy studies, guest editorial. Journal of Research in Reading, 16 (2).

Strickland, B. R. (1989). Internal-external control expectancies. American Psychologist, 44_(1), 1-12.

Van Dijk, T. A., \& Kintsch, W. (1983). Strategies of discourse comprehension. New York: Academic Press.

Vivaldo, L. J. (1992). Determinantes lingüísticos y psicológicos de la variabilidad del procesamiento del discurso académico escrito en lengua extranjera (inglés) en estudiantes universitarios. Master in Education Dissertation. Universidad Nacional Autónoma de México, México.
Vivaldo, L. J. (1994). Lectura y evaluación: Un enfoque estratégico. Imágenes Educativas, 1 (4), 3-13.

Williams, E., \& Moran, C. (1989). Reading in a foreign language at intermediate and advanced levels with particular reference to English. Language Teaching (The International Abstracting Journal of Language Teachers and Applied Linguists), Cambridge University Press.

Witkin, H., Oltman, P., Raskin, E., \& Karp, S. (1971). A manual for the Group Embedded Figures Test. Palo Alto, CA: Consulting Psychologist.

Recebido em: 19/12/02

Revisado em: 01/04/03

Aprovado em: 03/06/03 